\title{
The Effect Of Baby Solus Per Aqua (Baby Spa) To Sensory Skill, Fine Motor Skill And Gross Motor Skill In Children Aged 6-24 Months Di Wawa Holistic Care Mojokerto
}

\author{
Lida Khalimatus Sa'diya ${ }^{1}$,Tria Wahyuningrum² ${ }^{2}$, Lutfi wahyuni ${ }^{3}$, Yunika Nurtyas ${ }^{4}$ \\ 1,2,4 Midwifery Study Program STIKesBina Sehat PPNI Mojokerto \\ ${ }^{3}$ Nursing Study Program STIKesBina Sehat PPNI Mojokerto \\ Email: lidarafi2@gmail.com
}

\begin{abstract}
Abstrak
Pembinaan tumbuh kembang bayi harus dilakukan secara komprehensif dan berkualitas yang dapat dilakukan melalui kegiatan stimulasi. Stimulasi yang mudah diberikan secara aktif pada bayi dapat melalui stimulasi taktil yaitu dalam bentuk pijatan. Terapi pijatan dapat dikombinasikan dengan terapi air yaitu baby spa. Baby spa dapat digunakan untuk menunjang keberhasilan sensory skill, fine motor skill dan gross motor skill. Untuk mengetahui efektivitas Baby Spa terhadap sensory skill, fine motor skill dan gross motor skill pada anak usia 6 - 24 bulan. Desain yang digunakan dalam penelitian ini adalah pre eksperimental design dengan pendekatan two group pre post test. Variabel dalam penelitian ini adalah baby spa, sensory skill, fine motor skill dan gross motor skill. Responden adalah anak usia 6 sampai dengan 24 bulan berjumlah 29 anak untuk kelompok perlakuan dan 29 anak untuk kelompok kontrol. Kelompok perlakuan akan dilakukan treatment sebanyak 8 kali (2 kali baby spa dan 6 kali massage). Sebelumnya dilakukan pre test, kemudian setelah 8 kali treatment dilakukan post test dengan observasi sensory skill, fine motor skill dan gross motor skill. Analisis data dengan uji Mann-Whitney. Hasil analisa data pada sensory skill diperoleh nilai $p=0.962$ menunjukkan bahwa baby spa kurang efektif terhadap peningkatan sensory skill, sedangkan pada fine motor skill diperoleh nilai $p$ $=0.000$ dan gross motor skill diperoleh nilai $p=0.000$ artinya baby spa efektif terhadap peningkatan fine motor skill dan gross motor skill pada anak usia 6 sampai dengan 24 bulan. Kesimpulan Bahwa Baby Spa sangat efektif terhadap peningkatan fine motor skill dan gross motor skill namun pada sensory skill kurang efektif. Sehingga perlu stimulasi sensory skill dengan baby spa dan metode yang lain.
\end{abstract}

Kata Kunci : Baby Spa, Keterampilan Motorik Halus, Keterampilan Motorik Kotor

\begin{abstract}
Supporting of baby growth must be done in a comprehensive and quality manner that can be done through stimulation activities. Stimulation that is easily given actively to infants can be through tactile stimulation in the form of massages. Massage therapy can be combined with water therapy, which is a baby spa. Baby spas can be used to support the success of sensory skills, fine motor skills and gross motor skills. The study was to determine the effectiveness of Baby Spa on sensory skills, fine motor skills and gross motor skills in children aged 6-24 months. The design used in this study was a pre-experimental design with a two-group pre-post-test approach. The variables in this study are the baby spa, sensory skills, fine motor skills and gross motor skills. Respondents were children aged 6 to 24 months totaling 29 children for the treatment group and 29 children for the control group. The treatment group will be treated eight times (2 times baby spa and six times massage). Previously conducted a pre-test, then after eight treatments carried out a post-test with an observation of sensory skills, fine motor skills and gross motor skills data analysis using the Mann-Whitney test. The results of data analysis on the sensory skill
\end{abstract}


obtained $p$-value $=0.962$ indicates that the baby spa is less effective against increasing sensory skills, while the fine motor skill $p$-value $=0,000$ and gross motor skill obtained $p$-value $=0,000$ means that the baby spa is effective against increasing fine motor skills and gross motor skills in children aged 6 to 24 months. That the Baby Spa is very effective against increasing fine motor skills and gross motor skills but the sensory skills are less effective. So you need sensory skill stimulation with baby spas and other methods.

Keywords : baby spa, fine motor skill, gross motor skill

Article Info:

Article submitted on January 24, 2020

Articles revised on February 03, 2020

Articles received on March 12, 2020

DOI: http://dx.doi.org/10.21927/jnki.2020.8(2).134-140

\section{INTRODUCTION}

Early childhood is a group of children who are in a process of growth and development that is uniquely important to have a pattern of growth and physical development, intelligence, social emotional, language and communication(1). Supporting of growth and development of infants must be done in a comprehensive and quality manner that can be done through stimulation or stimulation activities. Perform adequate early stimulation means to stimulate the baby's brain so that fine motor function, gross motor and sensory function in infants take place optimally according to the child's age. Lack of stimulation provided to infants can cause delays in growth and development (2).

According to the World Health Organization (WHO) explained that $5-25 \%$ of preschool-aged children suffer from minor brain dysfunction, including impaired fine motor development. In Indonesia the number of babies is 23.7 million, $10.4 \%$ of the total population of Indonesia and obtained $16 \%$ of children under five years of age (toddlers) Indonesia experience neurological and brain development disorders ranging from mild to severe, impaired gross and fine motor development, hearing impairment, lack of intelligence and late speech (3). Based on the data above the importance of providing stimulation to children to optimize good growth and development in printing the next generation of quality nation.

Based on the results of research on gross motor development of infants through stimulation by mothers in Village of Kemayoran Surabaya by (4) in 30 infants aged $0-1$ years found $70 \%$ of mothers were not maximal in providing stimulation measures for infant development. Based on research (5), states that as many as $55.6 \%$ of toddlers aged $6-12$ months in the PosunganduKedungbendo Mojokerto District have undernourished status and almost half $(25 \%)$ have poor motor development. Malnutrition affects the gross motor delay in children.In this study the treatment group will be treated 8 times ( 2 times baby spa and 6 times massage). Children will be observed according to age and analyzed the effectiveness of baby spason their growthanddevelopment.

The stimulation provided can be given in the form of visual, verbal and tactile stimulation. Stimulations are easily given actively to infant scan be through tactile stimulation in the formof massages(6). Baby massage is a therapy in the form of touch massage that provides a stimulus to hormones in the body. One substance regulates functions such as appetite, sleep, sensory function, muscle contraction, metabolism and 
growth and development (7).Massage therapy can be combined with water therapy which is called a baby spa. The baby spa is a body therapy using water as a medium; its activities consist of swimming, bathing and massage. Babies treated with a spa will look fresher, healthier and more vibrant. Other benefits obtained by spas in infants are increasing the gross and fine motor movements of the baby, increasing the ability of the five senses, increasing appetite, improving the quality of sleep of the baby and increasing the baby's immunity(8).

One of the benefits of a baby spa is to improve the ability of the five senses including smell, sight, touch, hearing. For this reason, baby spas can be used to support the success of a sensory play. Sensory play is a sensory game or sensory responses of children. If a child can play the sensory game according to his age, the child is said to have successfully carried out a sensory play(9). In addition to the success of the sensory play, baby spas are also useful for enhancing development in children including gross motor skills and fine motor skills. Gross motor skill or gross motor ability is the ability to make movements that involve large muscles and form a posture such as raising the head, while fine motor skills or fine motor skills to make movements smoother and involve the flexibility of small muscles such as to pick up objects with radius(10).

The series of baby spa activities includea baby gym, baby gym ball, baby swim and massage. The purpose of this study was to measure the effectiveness of Baby Spa on Sensory skills, Fine Motor Skills and Gross Motor Skills in Children Ages 6-24 Months.

\section{METHODS AND MATERIALS}

The research design used in this study was pre-experimental design with a two-group pre-post design approach. The study population was children aged 6 months to 24 months who came to Wawa Holistic Care Mojokerto in good health from August until November 2019

The accidental sampling technique was 58 children. 29 children in the treatment group and 29 children in the control group. The treatment group will be treated 8 times in 1 month ( 2 times baby spa and 6 times massage). In this study, the treatment group will be treated 8 times in 1 month, namely 1 week 2 treatments (2 times baby spa in the first week and first treatment in the third week and 6 massages in the second, three, four, six treatment, seven and eight). For baby spas, the series of activities includes a 10 minute long baby gym, a 10 minute long baby gym ball, a 15 minute long baby swim and a 25 minute long baby massage, with a total of 1 hour baby spa time. Whereas the control group performed baby massage treatment 8 times for 1 month each week 2 times 1 hour massage treatment. One day after the last treatment the child will be observed according to age and analyzed the effectiveness of the baby spa on growth and development. In this study, the treatment group will be treated 8 times a month, namely 1 week 2 treatments (2 times baby spa and 6 times massage). Children will be observed according to age and analyzed the effectiveness of baby spas on their growth and development). Previously conducted a pre-test, then after 8 treatments carried out a post-test with an observation of sensory skills using a brief sensory profile instrument (PSS). For fine motor skills and gross motor skills, use the Denver Development Screening Test (DDST) instrument. Data analysis using the Mann-Whitney test. In the control group, pre-test and post-test were performed.

\section{RESULTS AND DISCUSSION}

Based on table 1 shows that the majority of respondents aged 13-18 months in the control group were 18 respondents $(62.1 \%)$ while in the experimental group were 17 respondents 
(58.6\%). The sex of the majority of women in the control group was 19 respondents $(65.5 \%)$ while in the experimental group were 17 respondents $(58.6 \%)$. Maternal age is more than half the age of healthy reproduction (20-30 years) both the control group and the experimental group. The age of the mother is more than half the age of 20-30years both the control group and the experimental group.

Table 1. Distribution of Respondent Characteristics

\begin{tabular}{lcccc}
\hline \multirow{2}{*}{ Category } & \multicolumn{2}{c}{ Control group } & \multicolumn{2}{c}{$\begin{array}{c}\text { Experimental } \\
\text { group }\end{array}$} \\
\cline { 2 - 5 } & $\mathbf{F}$ & $\%$ & $\mathbf{F}$ & $\%$ \\
\hline Age & & & & \\
6-12 month & 2 & 6.9 & 7 & 24.1 \\
13-18 month & 18 & 62.1 & 17 & 58.6 \\
18-24 month & 9 & 31 & 5 & 17.3 \\
gender & & & & \\
$\quad$ Female & 19 & 65.5 & 17 & 58.6 \\
$\quad$ Male & 10 & 34.5 & 12 & 41.4 \\
Mother age & & & & \\
20-30 years old & 22 & 75.9 & 24 & 82.7 \\
31-40 years old & 7 & 24.1 & 5 & 17.3 \\
\hline Total & 29 & 100 & 29 & 100 \\
\hline
\end{tabular}

Based on table 2 it can be seen the results of the pre-test that the development of sensory skills in the control group was mostly normal $(89.7 \%)$ with a total score of $155-190$ CNS but there were 3 respondents (10.3\%) whose development doubted the scoring of CNS 142154. While the experimental group was mostly normal $(86.2 \%)$ with a total score of CNS 155190 and 4 respondents whose development was doubtful (13.8\%) with a score of CNS 142-154.
Based on table 2 it can be seen the result the pre-test that the development of sensory skills in the control group was mostly normal $(89.7 \%)$ but there were 3 respondents $(10.3 \%)$ that development was low while in the experimental group the majority were normal $(86.2 \%)$ and 4 respondents that development was doubt (13.8\%).

The development of fine motor skills in the control group was mostly normal $(93.1 \%)$, but there were 2 respondents (6.9\%) that development was doubtful while in the experimental group the majority was normal (89.7\%) and 3 respondents that development was doubtful (10.3\%).

The development of gross motor skills in the control group was largely normal $(89.7 \%)$, but there were 3 respondents $(10.3 \%)$ that development was doubtful while in the experimental group,most were normal $(89.7 \%)$ and 3 respondents that development was doubtful (10.3\%).

Based on table 3 it can be seen the results of the post-test that the development of sensory skills in the control group was mostly normal $(93.1 \%)$ but there were 2 respondents $(6.9 \%)$ that development was doubtful while in the experimental group all were normal (100\%).

The development of fine motor skills in the control group was mostly normal (93.1\%), but there were 2 respondents (6.9\%) that development was doubtful while in the experimental group, most were normal (96.5\%) and 1 respondent that development was doubtful (3.5\%).

Table 2. Cross-tabulation of sensory skills, fine motor skills and Gross motor skills pre-test in the control and experimental groups

\begin{tabular}{lcccccccc}
\hline \multicolumn{1}{c}{ Variable } & Normal & $\%$ & Doubting & $\%$ & Deviations & $\%$ & Total & $\%$ \\
\hline Sensory skill & & & & & & & & \\
Control group & 26 & 89.7 & 3 & 10.3 & 0 & 0 & 29 & 100 \\
Experimental Group & 25 & 86.2 & 4 & 13.8 & 0 & 0 & 29 & 100 \\
Fine motor skill & & & & & & & & \\
Control group & 27 & 93.1 & 2 & 6.9 & 0 & 0 & 29 & 100 \\
Experimental Group & 26 & 89,7 & 3 & 10.3 & 0 & 0 & 29 & 100 \\
Gross motor skill & & & & & & & & 100 \\
Control group & 26 & 89.7 & 3 & 10.3 & 0 & 0 & 29 & 100 \\
Experimental Group & 26 & 89,7 & 3 & 10.3 & 0 & 0 & 29 & 100 \\
\hline
\end{tabular}

Source: Primary data 
Table 3. Cross-tabulation of sensory skills, fine motor skills and Gross motor skills post-test in the control and experimental groups

\begin{tabular}{lcccccccc}
\hline \multicolumn{1}{c}{ Variable } & Normal & $\%$ & Doubting & $\%$ & Deviations & $\%$ & Total & $\%$ \\
\hline sensory skill & & & & & & & & \\
Control group & 27 & 93.1 & 2 & 6.9 & 0 & 0 & 29 & 100 \\
Experimental Group & 29 & 100 & 0 & 0 & 0 & 0 & 29 & 100 \\
Finemotor skills & & & & & & & & \\
Control group & 27 & 93.1 & 2 & 6.9 & 0 & 0 & 29 & 100 \\
Experimental Group & 28 & 96.5 & 1 & 3.5 & 0 & 0 & 29 & 100 \\
Gross motor skill & & & & & & & & \\
Control group & 28 & 96.5 & 1 & 3.5 & 0 & 0 & 29 & 100 \\
Experimental Group & 28 & 96.5 & 1 & 3.5 & 0 & 0 & 29 & 100 \\
\hline
\end{tabular}

Source: Primary data

The development of Gross motor skills in the control group was mostly normal (96.5\%), but there was 1 respondent (3.5\%) that development was doubtful while in the experimental group the majority was normal (96.5\%) and 1 respondent that development was doubtful (3.5\%).

Based on the Mann-Whitney statistical test. The results of the analysis on sensory skills obtained $p$ value $=0.962$ shows that the baby spa is less effective against increasing sensory skills, while the fine motor skill pvalue $=0,000$ and gross motor skills obtained $p$ value $=0,000$ means that the baby spa is effective against increasing fine motor skills and gross motor skills in children aged 6 months to 24 months.

Based on tables 2 and 3 , it can be seen that the development of sensory skills, fine motor skills and Gross motor skills pre-test and post-test in the control and experimental groups almost all respondents have normal development abilities. In accordance with the SSP score table that the development of sensory skills is normal if the total score is 155-190, it is doubtful if the total CNS score is $142-154$ and the deviation if the total SSP score is $38-141$. Whereas Interpretation of DDST results is Normal if there is no delay or at most 1 (one) caution, Suspect if you get 2 (two) / more caution or if there is 1 or more delays and Untestable if there is a score rejecting one or more items on the left age line.

The results of the analysis of Mann-Whitney test that the development of fine motor skills and gross motor skills obtained values $p<0.005$ means that the baby spa is very effective against increasing the development of fine motor skills $p=0.000)$ and gross motor skills $(p=0.000)$ but different in the development of sensory skills where $p>0.05$ which means baby spa is less effective against increasing the development of sensory skills. This shows the important role of parents in providing stimulation of development in children, especially sensory skills.

The development of children in terms of learning, not only comes from genetic factors but also from the stimulus provided by the surrounding environment. When the stimulus enters the child's brain, the nervous system will then process it by producing a sensation that encourages the child's senses to move (stimulusresponse) in accordance with(11). The more stimulus provided, the more children will have a pleasant experience. Certainly, each stimulus will produce a different response, and it is the parents' job to facilitate their children to gain a lot of experience so that the brain's data bank is increasingly diverse.

The development of respondents' fine motor skills in the control group and the experimental group almost all of the respondents had normal fine motor skill development abilities, namely 27 children (93.1\%) in the control group and 26 children $(89.7 \%)$ in the experimental group. But there are still developments in doubting Fine motor skills in both the control and experimental 
groups. Fine motor skills where the child's ability to make movements that involve certain parts of the body and are carried out by small muscles, but require careful coordination, such as observing something, pinch, write, etc. This is in accordance with opinions, (12). The development of fine motor skills requires stimulation of the role of parents in order to achieve optimal child development.

Fine motor skills where the child's ability to make movements that involve certain parts of the body and are carried out by small muscles but require careful coordination, such as observing something, pinching, writing, etc. This is in accordance with opinions(12). The development of respondents' fine motor skills in the control group and the experimental group almost all of the respondents had normal fine motor skill development abilities, namely 27 children $(93.1 \%)$ in the control group and 26 children $(89.7 \%)$ in the experimental group. But there are still developments in doubting Fine motor skills in both the control group and the experimental group. This development needs the stimulation of the role of parents in order to achieve optimal child growth and development. In accordance with. The development of children in terms of learning, not only comes from genetic factors but also from the stimulus provided by the surrounding environment. When the stimulus enters the child's brain, the nervous system will then processit by producing a sensation that encourages the child's senses to move (stimulus response). The more stimulus provided, the more children will have a pleasant experience. Certainly, each stimulus will produce a different response, andit's the parents' job to facilitate their children to gain a lot of experience so that the brain's data bank is increasingly diverse.

Gross motor skills are developments related to the child's ability to make movements and postures involving large muscles, such as sitting, standing, walking, and so on (13). explained when the baby is experiencing rapid brain development certainly affects the gross motor and fine motor because touch stimulation is gradual and continuously stimulates the cerebral cymbals, the part of the brain that acts as the center of muscle movement and balance of the body so that it can optimize development. The development of respondents 'gross motor skills in the control group and the experimental group almost all respondents had normal Gross motor skill development abilities of 26 children $(89.7 \%)$, but there was still a development of the respondents' sensory skills which doubted both the control group and the experimental group which were 3 children $(10.3 \%)$. This shows the important role of parents in providing stimulation of development in children is needed. Referring to the results of the study of Kholifah, etal in 2014 on infant motor gross development through stimulation by mothers in the Kemayoran Village, Surabaya, in 30 infants aged $0-1$ years, $70 \%$ of mothers had not been maximal in providing stimulation for infant development. Like wise, the results of Susanti's study (2013), stated that as many as $55.6 \%$ of toddlers aged $6-12$ months in the Posyandu Kedungbendo Mojokerto District had under weight nutritional status and almost half $(25 \%)$ had poor motor development. Malnutrition affects the gross motor delay in children. This is consistent with the opinion Waimanetal 2016 that the development of children in terms of learning, not only comes from genetic factors but also from the stimulus provided by the surrounding environment. It is the task of parents to facilitate their children to gain a lot of experience so that the brain data bank isincreasinglydiverse. This is also supported by the results of his research (14), the results of the hypothesis test obtained a $p$ value of 0.038 , a probability value of less than 0.05 ( $p$ $<0.05$ ). From this statement there is a difference in the effect of giving baby massage and baby spa to increase gross motor babies under the age of 6 months. 
Based on the results of the mann-Whitney test obtained the probability value of fine motot skills ( $p$ value) of 0,000 and gross motor skills ( $p$ value) of 0,000 that the development of fine motor skills and gross motor skills obtained $p$ value $<0.005$ means that the baby spa is very effective against increasing fine development motor skills $(p=0,000)$ and gross motor skills $(p=0,000)$. From the statement, it means that the baby spa is very effective in increasing the development of fine motor skills and gross motor skills in children aged 6-24 months, which is conducted twice a week for 1 month.

\section{CONCLUSION AND RECOMMENDATION}

Baby spas are very effective for enhancing the development of fine motor skills and gross motor skills and gross motor skills. Parental stimulation is also important for optimal child growth and development in an effort to reduce the incidence of stunting in children.

For the development of sensory skills, a combination of baby spa stimulation needs to be combined with other methods to be more effective in improving children's development, and research into sensory skills has not been widely developed in Indonesia.

\section{REFERENCES}

1. Mutiah, D. (2015) The psychology of playing early childhood. Kencana.

2. Kementerian Kesehatan Republik Indonesia (2016) Situasi balita pendek, Jakarta: Info Datin Kemenkes RI. doi: ISSN 2442-7659.

3. Indonesian Central Bureau of Statistics (2013) Survei Demografi dan Kesehatan Indonesia 2012. (Indonesian Demographic and Health Survey, 2012 ), SDKI. doi: 10.1111/j.1471-0528.2007.01580.x.

4. Kholifah, S. N. et al. (2014) Perkembangan motorik kasar bayi melalui stimulasi ibu di kelurahan kemayoran Surabaya. Board for
Development and Empowerment of Human Resources in Public Health.

5. Susanti, W. (2013) 'Status Gizi Dan Perkembangan Motorik Kasar Pada Balita Usia 6-12 Bulan Di Posyandu Dusun Kedungbendo Desa Gemekan Kecamatan Sooko Kabupaten Mojokerto', Hospital Majapahit (Jurnal Ilmiah Kesehatan Politeknik Kesehatan Majapahit Mojokerto).

6. Kementerian Kesehatan Republik Indonesia (2016) Pedoman Pelaksanaan Stimulasi, Deteksi dan Intervensi Dini Tumbuh Kembang Anak, Summary for Policymakers. doi: 10.1017/CBO9781107415324.004.

7. Carr, H. (2013) 'Baby massage.', The practising midwife.

8. Melati, A. R. et al. (2019) 'Effect Of Solus Per Aqua (Spa) On Infant Weight', Belitung Nursing Journal. doi: 10.33546/bnj.154.

9. Mennella, J. A., Trabulsi, J. C. and Inamdar, L. (2014) '6. The sensory world of formulafed infants: differences among artificial milk feedings in flavor learning and satiation', in. doi: 10.3920/978-90-8686-223-8_6.

10. Gentier, I. et al. (2013) 'Fine and gross motor skills differ between healthy-weight and obese children', Research in Developmental Disabilities. doi: 10.1016/j.ridd.2013.08.040.

11. Waiman, E. et al. (2016) 'Sensori Integrasi: Dasar dan Efektivitas Terapi', Sari Pediatri. doi: 10.14238/sp13.2.2011.129-36.

12. Jannah, M. (2015) 'Tugas-tugas perkembangan pada usia kanak-kanak', Gender Equality: International Journal of Child and Gender Studies, 1(2), pp. 87-98.

13. Aw, S. 2011) 'Komunikasi interpersonal'. Yogyakarta: Graha IImu.

14. Taradiva, D. (2016) 'Perbedaanpengaruh Pemberian Massage Baby Dan Spa Baby Terhadap Peningkatan Gross Motor Pada Bayi Di Bawah Usia 6 Bulan'. Universitas' Aisyiyah Yogyakarta. 